\title{
Peat Soil Stabilization using Lime and Cement
}

\author{
Nadhirah Mohd Zambri ${ }^{1, *}$, and Zuhayr Md. Ghazaly ${ }^{1}$ \\ ${ }^{1}$ School of Environmental Engineering, University Malaysia Perlis, Kompleks Pusat Pengajian Jejawi \\ 3, 02600 Arau, Perlis, Malaysia
}

\begin{abstract}
This paper presents a study of the comparison between two additive Lime and Cement for treating peat soil in term of stabilization. Peat and organic soils are commonly known for their high compressibility, extremely soft, and low strength. The aim of this paper is to determine the drained shear strength of treated peat soil from Perlis for comparison purposes. Direct Shear Box Test was conducted to obtain the shear strength for all the disturbed peat soil samples. The quick lime and cement was mixed with peat soil in proportions of $10 \%$ and $20 \%$ of the dry weight peat soil. The experiment results showed that the addition of additives had improved the strength characteristics of peat soil by $14 \%$ increment in shear strength. In addition, the mixture of lime with peat soil yield higher result in shear strength compared to cement by $14.07 \%$ and $13.5 \%$ respectively. These findings indicate that the lime and cement is a good stabilizer for peat soil, which often experienced high amount of moisture content.
\end{abstract}

\section{Introduction}

Soils are normally used as construction for dams, embankment, and other earth structure. Ground improvement is a rapidly developing field because the good sites for construction are becoming limited day by day [1]. Therefore, soil is a key of component in construction industry.

Soft soils possess high water content and low workability allows an increase in the cost and duration of projects on soft soil [2]. Soft soils are known to have low strength, high compressibility and the water contents are also known to be high at almost to its liquid limits[3]. They are often unstable under structure and they are susceptible to problems from changes in moisture content [2]

Peat soil is a representative material of soft soils and classified as highly organic [4] $]^{1}$. Peat deforms greatly under applied loading on account of its exceptionally high water content and organic nature. Peat also has remarkably high strength compared with mineral soils at similar water content. In order to construct a safe, stable and serviceable road, road engineers have to overcome these engineering problems and find suitable solutions to construct roads on peat soil [5]. Peat is subjected to problems of instability such as local sinking and development of slip failure. It is also subjected to very large primary and long term settlement under an even moderate increase in load [6]. The peat soil is problematic

\footnotetext{
* Corresponding author: nadhirahazeela@gmail.com
} 
soil that will become more complex for construction process such as the construction of building and road [5]. The pile foundation is often recommended for the buildings on peat. However, the ground may still settle around the building. Also, sometimes the construction line such as road embankment is not only just subjected to only localized sink and development of the slip failure, but also large magnitude of primary and long term settlement $[6]^{2}$. There have been are many construction failures related to the inability of capturing this behaviour and so the proper model for compression and settlement prediction becomes a priority issue [7].

All materials deformed when subjected to loads. For soil, the load deformation relationship is usually complex, varying widely with different soils and particularly in the plastic range of cohesive soils, where time plays a major role [8][5]. The settlement increases in magnitude with an increase in load, although not linearly.

\section{Chemical Stabilizer}

Chemical stabilization is a major category of soil stabilization involving the use of chemical agents for initiating reactions within the soil for modification of its geotechnical properties [9]. The soil modification, stabilization, or both can be classified in group of soil improvement. Soil modification is an addition an active additives such as lime and cement for soil to change its index properties, while soil stabilization is the treatment of soils to improve the texture, increase strength, increase the CBR value and reduce shrink-swell characteristics such that they become totally suitable for construction for a long term [3].

A number of construction options that can be applied to peat and organic soils, namely excavation-displacement and reinforcement to enhance soil strength and stiffness, such as by stage construction and preloading, stone columns, piles, thermal precompression and preload piers, or by reducing driving forces by light- weight fill and chemical admixture such as cement and lime. These chemical admixtures can be applied either as deep in situ mixing method (lime-cement columns) or as surface stabilizer [10].

\subsection{Lime}

The additional of lime has an influence in reducing the optimum water content and increasing the maximum dry unit weight of dry density of the peat soil [11]. Lime has actually been used as a soil stabilizing agent since Roman time [11-12]. Lime was also used widely to stabilize weak fly ash to reduce settlement and to increase bearing capacity [3]. The hydrated lime $\left[\mathrm{Ca}\left(\mathrm{OH}_{2}\right)\right]$ was used as an additive for peat soil to improve some engineering properties of the soil. Quick lime is more efficient to effect change in soil strength compared with hydrated lime [11]. Lime soil reactions can be broadly classified into short term and long term reactions. The short term reactions include ion exchange, flocculation [13] and aggregation, carbonation [9,14] and pozzolanic [11].

\subsection{Cement}

Cement stabilization is the most common stabilization methods adopted for soil treatment. A Portland cement particle is a heterogeneous substance, containing minute tri-calcium silicate $\left(C^{3} S\right)$ dicalicum $\left(C^{2} S\right)$, tricalcium $\left(C^{3} A\right)$, and solid solution described as tetra calcium alumino-ferrite $\left(C^{4} A\right)$ [15][16]. When the pore water of the soil encounters with cement, hydration of the cement occurs rapidly and the major hydration (primary cementitious) produces hydrated calcium silicates $\left(\mathrm{C}^{2} \mathrm{SH}^{\mathrm{x}}, \mathrm{C}^{4} \mathrm{AH}^{\mathrm{x}}\right)$, and hydrated lime $\mathrm{Ca}(\mathrm{OH})^{2}[15][4]$. The addition of cement decrease the soils liquid limit [11]. The previous 
study state that addition of the chemical admixture, cement and lime, can improve the engineering properties of tropical peat soils [11]. Cement stabilization results in good compressive strength and is preferred for cohesionless to moderately cohesive soil but loses effectiveness in the case of highly plastic soil [9].

\section{Soil Stabilization in Peat Soil}

Peat is subjected to problems of instability such as local sinking and development of slip failure. Peat soil achieved the lowest shear strength with extremely soft and high organic content. The construction cost will reduce and effective stabilization by using lime and cement as the additive to stabilize the soil. During rainy seasons, weather related delays can be reduced by stabilizing the soil in order to continue site work. This can impact on the construction schedule in a positive way and save the cost of having to wait for good weather to continue work [17].

\section{Methodology}

\subsection{Peat Sample}

Peat samples were taken from paddy filed Jejawi, Perlis in the disturbed condition $0.3-0.6 \mathrm{~m}$ from the ground surface. All the samples were obtained using Mud Auger with two opening cylinder design and sharp edge at the end of the auger with $0.45 \mathrm{~m}$ of diameter and $1.56 \mathrm{~m}$ height and then they were placed into the plastic container sealed with aluminium foil to maintain the properties of peat soil like moisture content. The sample getting dried up in the oven with temperatures $105^{\circ} \mathrm{C}$ to $110^{\circ} \mathrm{C}$ in duration 24 hours (BS 377: Part 2: 1990). The dried up soil was then broken into pieces by using rubber hammer and were sieved passing through the sieve diameter $1.18 \mathrm{~mm}$.

\subsection{Direct Shear Box Test}

All the disturbed samples were tested under direct shear test with drained condition sample based on BS standard 1377:1990 (Part 7). The specimen was in square with the size $60 \mathrm{~mm}$ $\times 60 \mathrm{~mm} \times 25 \mathrm{~mm}$. Normal stress is applied are $136.2 \mathrm{kN} / \mathrm{m}^{2}, 272.5 \mathrm{kN} / \mathrm{m}^{2}$ and $408.8 \mathrm{kN} / \mathrm{m}^{2}$. The treated sample was prepared and tested with shear test. Each of a sample contained $10 \%, 20 \%$ of lime, $10 \%$ and $20 \%$ of cement.

\section{Results and discussions}

\subsection{Peat Properties}

The moisture content of Perlis peat soil is $327.14 \%$. High moisture content in peat is the main factor contributing to the characterization of peat with low bearing capacity and bulk density [18].

\subsection{Direct Shear Test}

By conducting these direct shear test, given that direct shear are considered as one of the most accurate testing techniques there is in geotechnical studies, it is possible to obtain the shear strength parameters of the stabilized soil, namely the friction angle, $\phi$ and the 
cohesion of soil, c. To ensure the accuracy of parameters calculations, all the tests were performed under three different pressures. In this research work, three normal stresses, $136.2,272.5$ and $408.8 \mathrm{kN} / \mathrm{m}^{2}$ was applied to determine shear properties of untreated and treated peat soil. The friction angle and cohesion of soil was determined from MohrCoulomb.

\subsubsection{Untreated Peat Soil}

Fig. 1 illustrates the shear displacement curve of the untreated and treated peat soil with different amount of additives. The load applied is $136.2 \mathrm{kN} / \mathrm{m}^{2}$. The internal friction angle of control sample was found to be $40.78^{\circ}$. Based on [19] the average effective angle of friction is $53^{\circ}$ for the peats and clearly above the average angle of $41^{\circ}$ for the organic soils. The relatively high value of friction angle at control sample can be anticipated due to the angular features of the sand particles. In the past found that the fibrous peat is in range $27^{\circ}$ $32^{\circ}$ under normal pressure $3-50 \mathrm{kN} / \mathrm{m}^{2}$. Besides that, in certain cases the friction angle is $50^{\circ}$ for amorphous granular peat and for fibrous peat is in range of $53^{\circ}-57^{\circ}$. The high friction angle does not represent the strength of the peat. However, it departs from the existence of fiber content in peat soil [20].

\subsubsection{Treated Peat Soil (Lime and Cement)}

Based on Fig. 1, 2, and 3 the experiment results show that the addition of lime and cement improve the strength properties of soil. The high of shear strength of peat will not actually reflect high of friction angle. This is because, [19] state that the fact the fibers are not always solid and may be filled with water and gas. From the all figure it can be observed that peat achieve the high shear strength with addition of lime compare to cement. The stabilizer such as lime and cement, depend on their chemical reaction with the soil elements in the presence of water and percent of the amount of stabilizer agent. The addition of lime $\left(\mathrm{Ca}^{+2}\right)$ strengthening the bond between the soil particle. The soil particle becomes closer to each other, causing the soil texture to change. The factors affecting lime treated soil are lime content, short period reaction and soil mineralogy. The cement reactions are time dependent and require long periods of time (years) because such reaction are functions of temperature, calcium quantity, $\mathrm{pH}$ value and percentage of silica in soil mineral[21].



Fig. 1. Graph shear stress vs displacement from direct shear box test for untreated and treated peat soil with normal stress applied $136.2 \mathrm{kN} / \mathrm{m}^{2}$. 


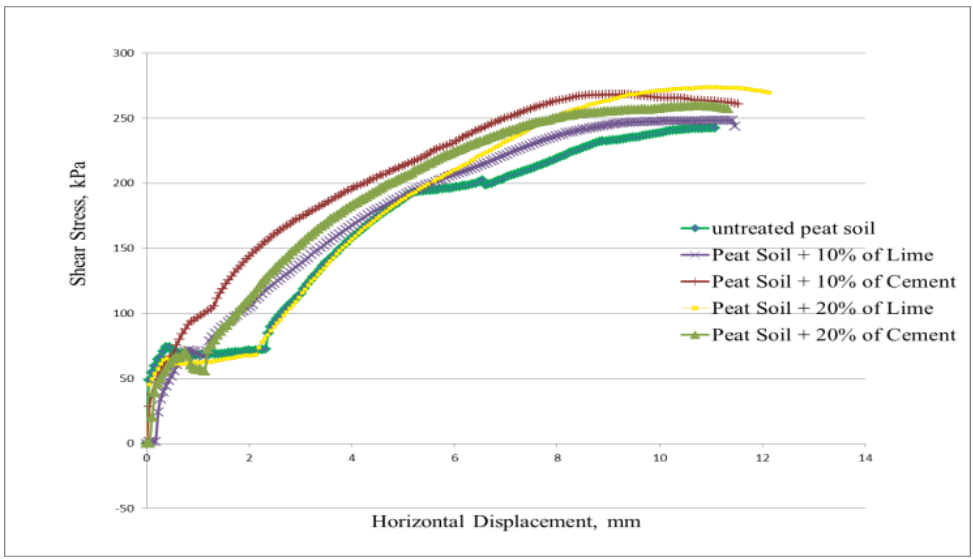

Fig. 2. Graph shear stress vs displacement from direct shear box test for untreated and treated peat soil with normal stress applied $272.5 \mathrm{kN} / \mathrm{m}^{2}$.

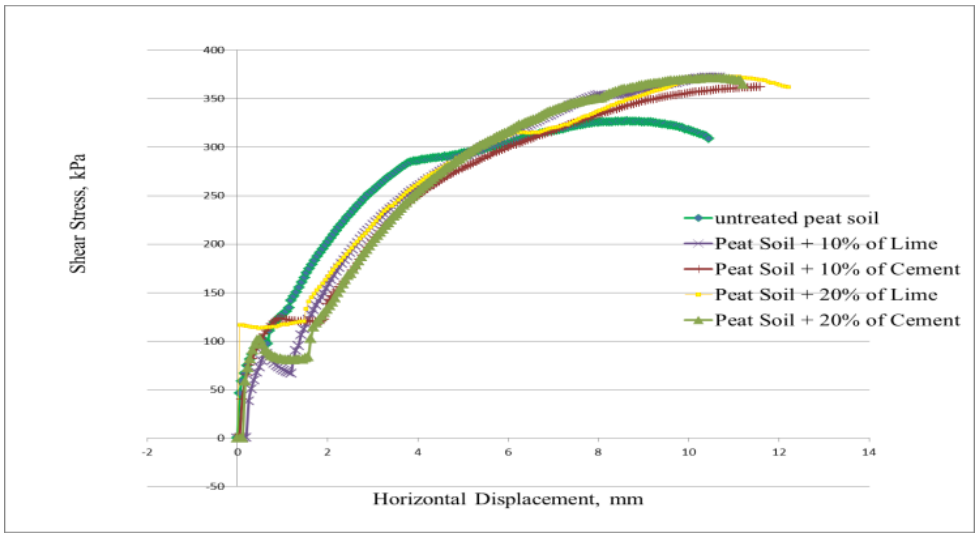

Fig. 3. Graph shear stress vs displacement from direct shear box test for untreated and treated peat soil with normal stress applied $408.8 \mathrm{kN} / \mathrm{m}^{2}$.

Table 1. Summary result of direct shear box test for Perlis peat soil for untreated and treated soil.

\begin{tabular}{|c|c|c|c|c|c|c|c|c|c|c|c|c|c|c|c|}
\hline $\begin{array}{l}\text { Figure } \\
\text { Number }\end{array}$ & \multicolumn{3}{|c|}{1} & \multicolumn{3}{|c|}{2} & \multicolumn{3}{|c|}{3} & \multicolumn{3}{|c|}{4} & \multicolumn{3}{|c|}{5} \\
\hline Sample & \multicolumn{3}{|c|}{ Control sample } & \multicolumn{3}{|c|}{$\begin{array}{c}\text { Peat soil }+10 \% \text { of } \\
\text { lime }\end{array}$} & \multicolumn{3}{|c|}{$\begin{array}{l}\text { Peat soil }+10 \% \text { of } \\
\text { cement }\end{array}$} & \multicolumn{3}{|c|}{$\begin{array}{c}\text { Peat soil }+20 \% \text { of } \\
\text { lime }\end{array}$} & \multicolumn{3}{|c|}{$\begin{array}{l}\text { Peat soil }+20 \% \text { of } \\
\text { cement }\end{array}$} \\
\hline $\begin{array}{l}\text { Stress } \\
\left(\mathrm{kN} / \mathrm{m}^{2}\right)\end{array}$ & 136 & 273 & 409 & 136 & 273 & 409 & 136 & 273 & 409 & 136 & 273 & 409 & 136 & 273 & 409 \\
\hline $\begin{array}{l}\text { Peak Shear } \\
\text { Stress } \\
\left(\mathrm{kN} / \mathrm{m}^{2}\right)\end{array}$ & 134 & 246 & 327 & 133 & 248 & 372 & 138 & 268 & 362 & 140 & 274 & 373 & 138 & 260 & 371 \\
\hline $\begin{array}{l}\text { Angle of } \\
\text { Shear } \\
\text { Resistance }\end{array}$ & \multicolumn{3}{|c|}{$40.78^{\circ}$} & \multicolumn{3}{|c|}{$41.24^{\circ}$} & \multicolumn{3}{|c|}{$40.05^{\circ}$} & \multicolumn{3}{|c|}{$34.44^{\circ}$} & \multicolumn{3}{|c|}{$41.05^{\circ}$} \\
\hline $\begin{array}{l}\text { Cohesion } \\
\left(\mathrm{kN} / \mathrm{m}^{2}\right)\end{array}$ & \multicolumn{3}{|c|}{27.72} & \multicolumn{3}{|c|}{21.79} & \multicolumn{3}{|c|}{28.40} & \multicolumn{3}{|c|}{50.09} & \multicolumn{3}{|c|}{17.66} \\
\hline
\end{tabular}

Based on the experiment results, the addition of lime and cement with percentages of mixing between $10 \%$ and $20 \%$ with peat give result in improving the strength characteristics of peat soil. The peak shear stress is also found to increase and the 
displacement with increase the normal stress. By treating the peat with lime and cement some of water in soil is replaced so that the density of soil will tends to increase on stabilization and those chemicals that increase the $\mathrm{pH}$ make an appropriate environment for stabilization process. This experiment result may be vary with others researcher as well known that the difference in fibrous content in peat. In addition, the deeper of peat soil the more decomposed is more consolidated.

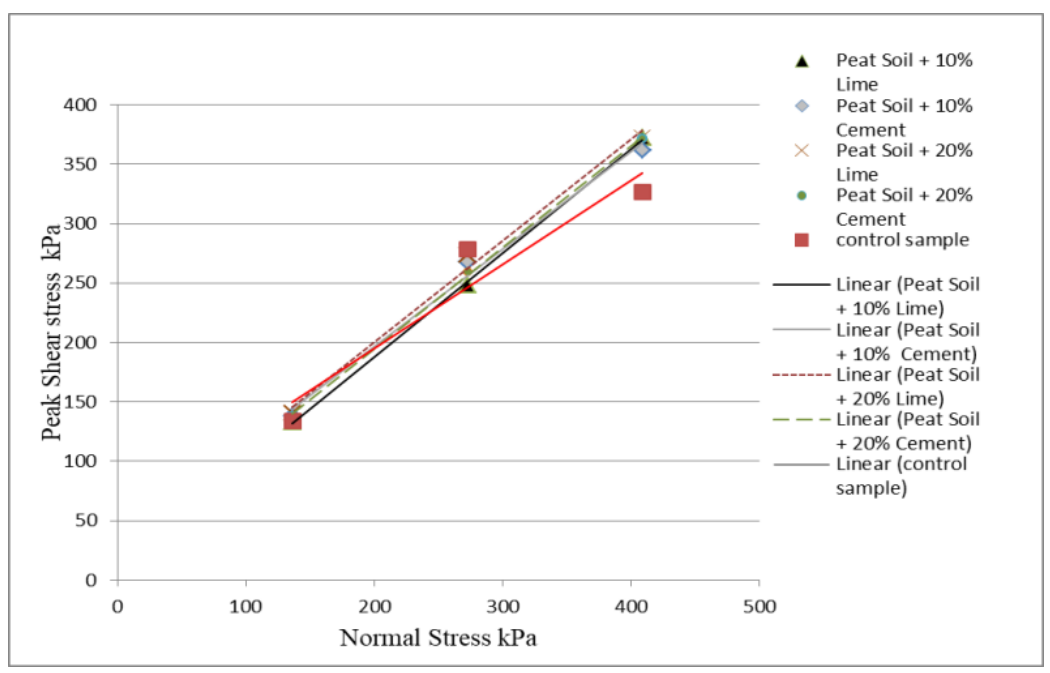

Fig. 4. Direct shear box test result for Perlis peat soil treated with $20 \%$ of cement with different of normal stress.

Fig. 4 shows the effect of additive to peat result from direct shear test for different amount of additive, with Mohr-Culomb lines fitted. In each case, cohesion, $\mathrm{C}$, is given by the $y$-intercept and angle of internal friction, $\phi$, by the line gradient. The additional of lime and cement may increase the strength for drained condition on peat. This is because the shear strength of peat is increased while the water content is decreased. Based on the figure, the specimens treated with the lime content reached the highest shear strength with the cohesion $50.09 \mathrm{kN} / \mathrm{m}^{2}$, resulting in a strength increase with the percentage of additive increase in comparison with the untreated peat strength while the peat treated with cement, the result shows decreased. It an be noticed from the Fig. 4 the cohesion and friction angle of peat treated with cement supposedly show the increased trend but in this experiment, the value is decreased than the raw sample. Based on that, the result may be increased if the percentage of cement will increase to $20 \%$ and above. On the other and, for others experiment sample that increase the percent of additives, the result of peat strength were even higher.

\section{Conclusions}

From the result of this study it can be concluded that addition of lime and cement will improve the strength characteristics of peat soil. The angle of shear resistance and cohesion of peat is found to increase significantly with increase in lime and cement content. The performance of lime is better than the cement in term of shear strength of peat soil. It can be prove by the result of shear stress for treated peat ( $20 \%$ of lime) increased $14.07 \%$ from untreated soil compare the increment of shear stress for treated peat (20\% of cement) increased $13.5 \%$ from untreated soil. The relationship between shear strength and peat soil stabilized by different stabilized agent and amount is less significant strength gain unless 
cement is added to the soil in large dosage. Stabilization of organic soil with lime and cement will reduce the damage and destruction of the superstructure. Furthermore, the strength of peat can increase in term of stabilization, improve the deformation properties and cost saving.

This work was financially supported by Ministry of Higher Education Malaysia (MOHE) under Research Acculturation Grant Scheme (RAGS) 2015, No. 9018-00088. This support is gratefully acknowledged.

\section{References}

1. S. Boobathiraja, P. Balamurugan, M. Dhansheer, A. Adhikari, Int J Civ Eng Res 5, 4, 431-438, (2014)

2. A. I. M. Ismail, Z. L. Belal, Nat. Sci. 12, 3, 73 - 78, (2014)

3. N. Khalid, M. Mukri, F. Kamarudin, N. Sidek, M. F. Arshad, InCIEC 2013, (Springer Singapore, 2014)

4. S. Deboucha, R. Hashim, and A. Alwi, J. Geotech. Eng-EJGE. 13, 1-9, (2008)

5. S. N. M. Razali, I. Bakar, A. Zainorabidin, Procedia Eng. 53, 145-155, (2013)

6. S. Kazemian, A. Prasad, B. B. K. Huat, M. Barghchi, Int. J. Phys. Sci. 6, 8, $1974-$ 1981, (2011)

7. E. Papadaki, Modelling of Peat Compressed under Sand Bodies: Experimental and Numerical Approach, (Doctoral dissertation, Master thesis at Technical University Delft, 2013)

8. J. N. Cernica, Geotechnical engineering: soil mechanics, (Wiley, 1995)

9. J. James, P. K. Pandian, Adv. Civ. Eng. 2016, 2016.

10. T. B. Edil, Proc. 2nd Int. Conf. Soft Soil Eng. Technol. (Putrajaya, Malaysia, 2003)

11. B. B. K. Huat, S. Maail, T. A. Mohamed, Am. J. Appl. Sci. 2, 7, 1113-1120, (2005)

12. P. F. F. Lancaster-Jones, E. McKeand, F. G. Bell, Foundation engineering in difficult ground, (London, Boston, Newnes-Butterworth, 1978)

13. S. Bhuvaneswari, T. Thyagaraj, R. G. Robinson, S. R. Gandhi, Indian Geotechnical Conference-2010, GEOtrendz, 609-612, (2010)

14. Z. Metelková, J. Boháč, R. Přikryl, I. Sedlářová, Appl. Clay Sci. 61, 37-43, (2012)

15. D. T. Bergado, Proc. of the seminar on ground improvement application to Indonesian soft soils, (Indonesia: Jakarta, 1996)

16. R. Hashim, M. S. Islam, Electron. J. Geotech. Eng. 13, 1-9, (2008)

17. G. R. Otoko, Int. J. Eng. Technol. Res. 2, 5, 1-6, (2014)

18. N. M. Sa'don, A. R. A. Karim, W. Jaol, W. H. W. Lili, UNIMAS e-Journal Civ. Eng. 5, 6-12, (2015)

19. B. B. K. Huat, A. Prasad, A. Asadi, S. Kazemian, Geotechnics of organic soils and peat. (CRC Press, 2014)

20. H. Moayedi, R. Nazir, Geotech. Geol. Eng. 1-11, (2017)

21. I. T. Jawad, M. R. Taha, Z. H. Majeed, T. A. Khan, Res. J. Appl. Sci. Eng. Technol. 8, 4, 510-520, (2014) 